\section{Acknowledgement}

Mr Simon Brighton printed the inversion of the photograph of the Mona Lisa.

\section{References}

Clark, K. (1988) Leonardo da Vinci. London: Viking.

DAvid, A. S. \& Cutring, J. (1990) Affect, affective disorder and schizophrenia. A neuropsychological investigation of right hemisphere function. British Journal of Psychiatry, 156, 491-495.

Freud, S. (1917) The Development of the Libido and the Sexual Organisations. Introductory lectures on psychoanalysis. 362-382. London: Penguin Books.
(1910) Leonardo da Vinci and a memory of his childhood. The Complete Psychological Works of Sigmund Freud, Vol.11. London: The Hogarth Press.

LeVY, J. et al (1972) Perception of bilateral chimeric figures following hemisphere deconnection. Brain, 95, 61-78.

SCHWARTZ, L. (1986) January edition. Art and Antiques.

SKINNER, M. (1989) Face to face with asymmetries in facial expression. The Psychologist: Bulletin of the British Psychological Society, 10, 425-427.

SMETACEK, V. (1992) Mirror-script and left handedness. Nature, 355, 118-119.

SPERRY, R. W. (1977) Forebrain commisurotomy and conscious awareness. The Journal of Medicine and Philosophy, 2, 101-126.

\title{
The use of car telephones by psychiatrists
}

\author{
J. A. Henderson, Registrar; C. J. Simpson, Consultant Psychiatrist; and \\ J. D. MUMFord, Consultant Psychiatrist, Department of Mental Health, \\ Friarage Hospital, Northallerton, North Yorkshire DL6 1JG
}

As community services develop, medical staff are increasingly spending more time outside the hospital, despite the most severely ill patients still being in hospital. This may lead to junior medical staff and nurses feeling unsupported by the consultant. In addition, as more disturbed patients are kept out of hospital, the general practitioner and community health workers may require to contact the psychiatrist more often to talk about patients or to request urgent assessment. Therefore the importance of communication with consultants is increased both from the hospital and from the community while they are spending increasing amounts of time in their cars. In a discipline where communication is of paramount importance, a failure to meet this growing need would undermine the effectiveness of the service as a whole.

In Northallerton Health Authority this is a particular problem as it covers 1,000 square miles and is essentially rural. It includes the northern part of the Vale of York, Wensleydale, Swaledale and the western fringes of the North Yorkshire Moors (Simpson, 1989). It was therefore decided that the two consultant psychiatrists should each have a car telephone and that this be evaluated in terms of cost, avail- ability for discussion of patients with community and hospital staff, as well as contactability in an emergency.

At the time of the study, the two psychiatrists in the district had in-patient beds outside the district, one to the North and one to the South. However, they both did out-patient clinics and domiciliary work throughout their sectors and ran community day hospitals, a hospital hostel and dementia assessment wards within the district. They both spent many hours travelling in their cars and found that whenever they got to their destination they had a list of telephone calls to make.

\section{The study}

The study was divided into two parts; a study on cost and a study on quality.

In order to study the cost, all incoming calls to the car telephones were recorded over one year by one of the consultants. Each of these calls was rated as emergency or routine and the clinical consequences of being able to use the car telephone were noted. For each call an estimate was made of the time saved as a result of using the car telephone. In addition all 
outgoing calls and their costs were recorded by an itemised bill. The time saved by each telephone call was translated into money by determining the time save in terms of the consultant's average income. This was done by calculating the amount of pay the consultant receives per minute based on his average salary and the minimal hours contractually worked. This information was kept blind from the consultant until the end of the study.

In order to study quality two different aspects of communication were measured; the availability to discuss patients with each consultant and also how easy it was to contact the consultants in an emergency. A questionnaire was sent to GPs, community and ward staff at the beginning of the study and after one year of the study. The questionnaire used a seven point scale known as the delighted/terrible scale whose validity and reliability had previously been studied (Lehman et al, 1982) and the respondents were asked two questions:

1. How satisfied are you with the availability of $\mathrm{Dr}$ $\mathrm{X}$ ?

2. In the case of an emergency, how satisfied are you with the contactability of Dr X?

The results were analysed using the Mann Whitney-U test.

\section{Findings}

With regard to cost, the running of the car telephone for one year for one consultant totalled £527.23p including VAT. This included the rental, itemised bills and telephone calls, but excluded the initial instalment. The money saved by the use of the car telephone totalled $\mathbf{1 3 9 1}$. Therefore the total actual cost of running a car telephone for one year by one consultant was $£ 136.23 p$.

The response rates to the questionnaires regarding both consultants was $84 \%$ at the beginning of the study and $81 \%$ at the end of the study. The mean results on the seven point scale for availability of the consultants at the beginning of the study was 5.57 and at the end of the study was 5.39, which was not significant. However, for emergency contactability the scores increased from 4.67 before the study to 5.48 at the end of the study which was significant $(P<0.005)$.

\section{Comment}

A literature search showed no similar study has been performed in using car telephones to aid communication in mental health.
The final costing of $£ 136.23$ for a year's use of the car telephone was much less than we had previously estimated. The use of itemised bills allowed checking of the forms filled in by the consultant against the bill and these were shown to tally exactly. This, therefore, excludes the possibility of inaccuracy which could be a problem with such a study relying on a consultant to fill in a form for each telephone call made. The costings are therefore considered to be accurate, although it has to be noted that the time saved in terms of consultant time was an estimate made at the time of the call. In addition, the calculation of cost of consultant's time is based on minimal contractual working hours which is, of course, an underestimate of what most consultants work. Any time saved is also an invisible saving in reality, as that money is not recouped by the health authority but by the consultants working less hours in excess of their contractual commitments.

The response rates were good for both questionnaires. There was no change in the availability of the consultants to discuss patients with community or ward staff over the period of the study. There was, however, a highly significant improvement in how contactable the consultants were in an emergency. In a remote area of North Yorkshire this should provide enormous benefits, as difficulties contacting the appropriate medical personnel required to deal with psychiatric emergencies cause considerable distress for patients and relatives. It could also improve standards of hospital care and nursing staff morale. This study does not allow for the calculation of savings in terms of GPs' time, which similarly should show improvements if consultants are more readily available.

The consultants involved in the study both greatly valued the use of the car telephones and have continued to use them since the study. Their impression is that they are more available and more able to deal with urgent and non-urgent issues while travelling around in their cars. In the past this had been wasted time, but it can now be used constructively.

\section{Acknowledgement}

This study was supported by a grant from Rhône-Poulenc Rorer Ltd.

\section{References}

Lehman, A. F., Ward, N. C. \& LinN, L. S. (1982) Chronic mental patients: the quality of life issue. American Journal of Psychiatry, 10, 1271-1276.

SimPSON, C.J.(1989)All patients great and small. Psychiatric Bulletin, 13, 605-606. 